\title{
ARTIKELEN
}

\section{Martha Nussbaums Anger and Forgiveness}

\section{Over vergelding en vergeving en over woede en liefde}

\author{
Jacques Claessen
}

\author{
'Anger and aggression sometimes seem to be protective \\ because they bring energy to bear on a particular situation, \\ but what needs to be acknowledged is that that energy is blind. \\ It takes a calm mind to be able to consider things \\ from different angles and points of view.' \\ De Dalai Lama ${ }^{1}$ \\ 'Love and compassion are necessities, not luxuries. \\ Without them humanity cannot survive.' \\ De Dalai Lama ${ }^{2}$
}

\section{$1 \quad$ Inleiding}

Volgens de Britse filosoof Scarre is vergeving 'a fairly open-ended concept', hetgeen 'any simple generalisation' uitsluit (Scarre, 2004: 19 en 32). Niettemin wordt doorgaans onderscheid gemaakt tussen voorwaardelijke en onvoorwaardelijke vergeving, waarbij voorwaardelijke vergeving vaak niet als 'volwaardige' of 'echte' vergeving wordt beschouwd (zie o.a. Derrida, 2001; Tutu \& Tutu, 2014: 20-21; Claessen, 2017: 25-27). Sterker nog, wanneer bijvoorbeeld een slachtoffer onder invloed van een bekentenis, excuses en/of schadevergoeding die hem door de dader worden aangeboden, afziet van proportionele wraakneming, dan heeft dat volgens verscheidene denkers niet zozeer met vergeving (en liefde) als wel met een vorm van vergelding (en rechtvaardigheid) te maken, waaruit blijkt dat vergelding ook iets anders dan proportionele wraakneming kan inhouden (zie o.a. Bianchi, 1964; Van Tongeren, 2013: 83; Claessen, 2017: 20-25).

De Amerikaanse filosofe Martha Nussbaum gaat in haar boek Anger and Forgiveness (2016) nog een stap verder. Niet alleen maakt ook zij onderscheid tussen voorwaardelijke en onvoorwaardelijke vergeving én brengt zij voorwaardelijke vergeving in verband met de 'vergeldingslogica', tevens keurt zij vergelding en in het verlengde daarvan voorwaardelijke vergeving op morele gronden af. Deze morele afkeuring hangt samen met Nussbaums inmiddels vrijwel categorische 
afwijzing van woede, die volgens haar intrinsiek deel uitmaakt van vergelding alsook van voorwaardelijke vergeving. Woede, zo luidt Nussbaums pleidooi in Anger and Forgiveness, dient plaats te maken voor onvoorwaardelijke liefde. Uitsluitend gedrag dat voortkomt uit een geest van onvoorwaardelijke liefde, kan als moreel worden gekwalificeerd; soms maar lang niet altijd kan onvoorwaardelijke vergeving worden beschouwd als vorm van onvoorwaardelijke liefde. Deze ideeën over woede, vergelding, vergeving en liefde past zij vervolgens onder meer toe op het politieke domein, waartoe ook het strafrecht behoort. ${ }^{3}$ Nussbaum pleit dan voor een strafrecht zonder woede en vergelding; in Nussbaums strafrecht is enkel ruimte voor preventie en menselijk welzijn.

Anger and Forgiveness is zonder meer een prikkelend en uitdagend werk, geschreven door één van de meest invloedrijke denkers van deze tijd. Alleen al om die reden verdient het aandacht. Nussbaum biedt een alternatieve visie op - ook voor het herstelrecht belangrijke - concepten als woede, vergelding, vergeving en liefde en ze houdt een vurig pleidooi voor een strafrecht zonder woede en vergelding. Van deze alternatieve visie en dit vurige pleidooi kunnen we naar mijn mening zeker wat leren, maar Nussbaums radicaliteit geeft onvermijdelijk ook aanleiding tot kritiek. Deze bijdrage is als volgt opgebouwd. Eerst sta ik kort stil bij Nussbaums vroegere visie op woede (par. 2). Vervolgens zet ik Nussbaums ideeën uit Anger and Forgiveness uiteen (par. $3 \mathrm{t} / \mathrm{m}$ 13). Tot slot bespreek ik Nussbaums gedachtegoed kritisch aan de hand van mijn eigen visie (par. 14 t/m 20).

\section{Woede anno 2001}

In haar boek Upheavals of Thought (2001) ontwikkelt Nussbaum mede op basis van het stoïcisme ${ }^{4}$ van Seneca een cognitieve emotietheorie volgens welke emoties als een belangrijke bron van kennis gelden; emoties zijn als het ware 'oplevingen van het denken'. Een emotie is eerst irrationeel, wanneer zij een opleving vormt van een irrationele gedachte. Nussbaums antwoord op de vraag welke gedachten rationeel en welke gedachten irrationeel zijn, hangt in feite samen met het onderscheid dat zij maakt tussen positieve en negatieve emoties; negatief zijn volgens haar emoties die een mens afsluiten voor zijn medemens, positief zijn emoties die een mens voor zijn medemens openstellen. Grosso modo neemt Nussbaum het standpunt in dat negatieve emoties op irrationele gedachten berusten en dat de gedragingen die hieruit voortvloeien, immoreel zijn.

In de tijd van het verschijnen van Upheavals of Thought maakt Nussbaum nog een scherp onderscheid tussen woede en wrok/wraakzucht..$^{5}$ In tegenstelling tot wrok/wraakzucht is woede volgens haar niet noodzakelijk een emotie die op irra-

3 Zie voor Nussbaums pleidooi voor meer liefde en mededogen in het politieke domein ook: Nussbaum 2013.

4 Het stoïcisme is een filosofische stroming die ca. 300 v.Chr. in Griekenland is ontstaan en behoort tot de zogeheten hellenistische filosofieën. Bekende stoïcijnen zijn Zeno, Seneca, Epiktetos en Marcus Aurelius.

5 Zie o.a. Breebaart, 2016; Giesen \& Braams, 2005; Wit, 2004. 
tionele gedachten is gebaseerd. Achter woede kan namelijk de rationele gedachte schuilgaan dat een bepaalde gedraging simpelweg niet hoort. Zo zal iemand die getuige is van een mishandeling, daar, als het goed is, boos om worden, aldus Nussbaum. Woede vormt dan de opleving van de rationele gedachte 'gij zult een ander niet schaden' en kan gepaard gaan met morele verontwaardiging en de drang om degene die mishandelt, terecht te wijzen wegens zijn gedrag. Uit woede kan echter ook wrok/wraakzucht voortvloeien, maar dat hoeft niet. Achter wrok/ wraakzucht gaat volgens Nussbaum de irrationele gedachte schuil dat, wanneer een persoon iemand anders schaadt, ook die persoon (in het genoemde voorbeeld: degene die mishandelt) moet worden geschaad.

Wat opvalt, is dat Nussbaum ruimschoots voor het verschijnen van Anger and Forgiveness in ieder geval de facto al onderscheid maakt tussen enerzijds wat zij in het laatstgenoemde boek 'transitiewoede' noemt (zie par. 4) en anderzijds woede waarin de drang om terug te slaan besloten ligt. Echter, terwijl Nussbaum tegenwoordig nog maar weinig fiducie in woede heeft (woede hangt nu volgens haar wel in de regel samen met wrok/wraakzucht), was ze vroeger een warm voorstander van woede (woede was toen volgens haar in beginsel 'transitiewoede'), zo kan uit het volgende fragment uit Upheavels of Thought worden afgeleid:

'Kortom, we moeten eenvoudig ontkennen dat de excessen van woede voldoende reden zijn om deze emotie volledig uit te bannen. We moeten de stoïcijnen duidelijk maken dat woede soms gerechtvaardigd en goed is. Het is een passende reactie op onrechtvaardigheid en ernstig wangedrag. Als we woede uitbannen verdwijnt er ook een belangrijke kracht om sociale rechtvaardigheid te bewerkstelligen en op te komen voor de onderdrukten. Als we bang zijn dat woede zich op oneigenlijke objecten richt, dan moeten we dat probleem aanpakken en niet proberen de woede zelf volledig uit te wissen. Ook als we bang zijn dat sommige boze mensen uit zijn op ongepaste persoonlijke wraak en geen in de wet vastgelegde oplossingen willen accepteren, is dat het probleem dat we moeten aanpakken en we moeten dan niet proberen de woede volledig uit te bannen' (Nussbaum, 2001: 337). ${ }^{6}$

\section{Woede sinds 2016}

Zoals reeds in het voorgaande gezegd: inmiddels keurt Nussbaum woede vrijwel categorisch af. Nussbaums redenering - vooral gebaseerd op het eudemonisme ${ }^{7}$ van Aristoteles en het stoïcisme van Seneca ${ }^{8}$ - luidt als volgt. Het idee van vergelding in de zin van wraakneming oftewel een ander willen laten lijden voor begaan

$6 \quad$ Zie in dit verband ook: Gryson \& De Waele, 2018.

7 Het eudemonisme is een ethische leer ontwikkeld door de Griekse filosoof Aristoteles en houdt het streven naar geluk in.

8 Nussbaum volgt Seneca nu radicaler dan voorheen. Immers, Seneca wijst woede af, terwijl Nussbaum eerst in Anger and Forgiveness woede vrijwel categorisch afwijst. Zie over de stoïcijnse visie op woede van onder anderen Seneca: Van Reijen, 2000, hoofdstuk 9; Van Reijen, 2016, hoofdstuk 2. 
onrecht, maakt deel uit van het concept woede. Woede kent een 'dubbele beweging': een terugblikkend oordeel ( $\mathrm{er}$ is mij onrecht aangedaan) en een daarmee verbonden toekomstgerichte neiging tot handelen (ik wil dat de ander hiervoor lijdt) (p. 33-35). ${ }^{9}$ Hoewel vergeldingsdrang/wraakzucht diep in de menselijke 'verbeeldingswereld' geworteld is (p. 37), is vergelding/wraak normatief gezien problematisch, want:

1 door de ander te laten lijden wordt de door die ander veroorzaakte schade niet opgeheven of goedgemaakt (het evenwicht wordt niet hersteld);

2 terwijl de 'toegebrachte ego-wond' door de ander te laten lijden wel kan worden geheeld (door het onrecht dat mij is aangedaan wordt mijn relatieve status verlaagd en door de dader te laten lijden wordt mijn status verhoogd of in ieder geval wordt de relatieve status van de dader verlaagd), is deze redenering ethisch gezien laakbaar. Immers, ieder mens heeft gelijke waardigheid en een mens hoort niet, wanneer een ander zijn waardigheid schendt, nu ook de waardigheid van die ander te schenden: 'Waardigheid is geen nulsomspel; als zodanig is het iets heel anders dan relatieve status' (p. 39-40). ${ }^{10}$

$\mathrm{Nu}$ vergelding normatief gezien problematisch is, geldt volgens Nussbaum hetzelfde voor woede, waarvan de idee van vergelding zogezegd deel uitmaakt. Achter woede kunnen twee 'nefaste dwalingen' schuilgaan: 'een vruchteloze focus op magische ideeën van vergelding' of 'een onderliggende obsessie met relatieve status' (p. 44).

\section{Transitiewoede bij het slachtoffer}

Nussbaum vindt dat er alleen nog legitieme ruimte is voor wat zij 'transitiewoede' noemt, dat wil zeggen woede gericht op 'het creëren van toekomstig welzijn' en waarvan vergelding/wraak, die juist aan toekomstig welzijn in de weg staat, geen deel uitmaakt (p. 43 en 301). Alleen transitiewoede is rationele woede. Alle andere vormen van woede zijn irrationeel, want gebaseerd op magisch vergeldings- of obsessief statusdenken; elders spreekt Nussbaum van 'de dwaalwegen van de vergeldingsfantasie en/of statusobsessie’ (p. 69). Simpel gezegd heeft transitiewoede de volgende inhoud: 'Wat een schande! Daar moet iets aan gedaan worden', terwijl reguliere woede als inhoud heeft: 'Wat een schande! Hiervoor moet de dader lijden' (p. 49). Nussbaum benadrukt hoe 'zeldzaam en exceptioneel deze pure toekomstgerichte emotie' is, want het verlangen naar vergelding/wraak is in de regel in woede aanwezig - hoe 'subtiel' en 'heimelijk' ook (p. 50-51). Dat maakt dat zij

9 Alle paginanummers in de tekst verwijzen naar de Nederlandse vertaling: Nussbaum 2016b. Zo ook: Jacobs, 2008, p. 204: '[...] wil je het iemand op wie je kwaad bent, betaald zetten, en je wilt hem dat laten voelen ook; dat je wilt dat hij eronder lijdt, kan daarom, zegt Aristoteles, worden getemperd door medelijden'; Van Reijen, 2000, p. 191: 'Alle emoties zijn [...] een “actiebereidheid" en in het geval van de "agressieve gevoelens" [...] zal de actie een agressieve handeling zijn. [...] Deze agressieve handelingen, die uit woede [...] voortkomen, zijn [...] uiteindelijk het gevolg van cognitie: de gedachte aan aangedaan onrecht, en de behoefte om de ander leed en zichzelf een beter gevoel te bezorgen.'

10 Zie over de (normatieve) voor- en nadelen van vergelding/wraak ook: Frijda, 2008, hoofdstuk 10. 
woede, niet zijnde transitiewoede, afwijst, hoe nuttig deze ook kan zijn, bijvoorbeeld ter signalering dat er iets mis is, ter motivatie om wat mis is te corrigeren en ter afschrikking om wat mis is nogmaals te begaan (p. 51-55). In haar huidige visie (die overigens wordt gedeeld door andere denkers ${ }^{11}$ ) is woede echter niet noodzakelijk ter signalering, correctie en afschrikking en wegen de positieve kanten niet op tegen de negatieve, namelijk de in woede - niet zijnde transitiewoede - besloten liggende vergeldingsdrang/wraakzucht.

\section{$5 \quad$ Zelfwoede bij de dader}

Nussbaum besteedt tevens aandacht aan zelfwoede, die volgens haar vaak een vorm van transitiewoede is en daarmee 'een bijzonder belangrijke kracht voor morele verbetering' is (p. 153). Dat is in ieder geval zo wanneer woede de volgende inhoud heeft: 'Wat afschuwelijk! Laat ik ervoor zorgen dat ik dat niet meer doe' (p. 153). Een dergelijke woede is constructief en toekomstgericht. Zelfwoede kan volgens Nussbaum overgaan in schuld(besef). Evenals woede - maar anders dan haat en schaamte - is schuld(besef) gericht op daden en niet op iemands persoon. Dat beschouwt zij als positief, omdat daad en dader dan van elkaar gescheiden worden. Ook positief acht zij - via de focus op de daad - de gerichtheid op de schade aan (de relaties met) anderen. Problematisch is echter dat veel zelfwoede in de zin van schuld(besef) gepaard gaat met het pijnigen van zichzelf, wat in feite een vorm van vergelding is:

'Schuldbesef houdt in dat je jezelf pijn doet, met het idee dat je deze pijn verschuldigd bent. Pijn is inderdaad een vast onderdeel van de emotie. Deze pijn drukt "vijandigheid jegens jezelf" uit. [...] We hebben geen aan onszelf opgelegde pijn nodig om onszelf te corrigeren en anderen te helpen. [...] Een positieve liefde voor [jezelf en, toev. JC] anderen [...] lijkt een toereikend en veel minder problematisch motief voor moreel gedrag. [...] pijn lost het werkelijke probleem niet op [...]' (p. 155-156).

\section{Vergeving}

$\mathrm{Na}$ het primaire thema woede te hebben behandeld, gaat Nussbaum over tot een bespreking van vergeving, het tweede thema in Anger and Forgiveness. De vraag die zij zichzelf stelt, is of vergeving 'een geschikte kandidaat is die woede zou kunnen vervangen als primaire houding jegens wandaden die mensen begaan' (p. 20). Zij definieert vergeving als 'een proces tussen twee personen dat het tot bedaren brengen van woede en het stoppen met wraakplannen inhoudt' (p. 74). Zelf heb ik vergeving omschreven als 'the (partial) refraining by the victim of moral evil from retaliation (the external process) through (partially) overcoming negative feelings towards the offender (the internal process)', in het kader waarvan bij negatieve emoties primair aan woede dient te worden gedacht (Claessen, 2017: 25). Opval- 
lend is dat ook Nussbaum in haar definitie een innerlijk en een uiterlijk proces onderscheidt, waaruit direct het verband blijkt tussen woede (innerlijk) en vergelding/wraak (uiterlijk). Tevens volgt ook uit Nussbaums definitie dat voor vergeving de uitgangspositie na misdaad bestaat uit woede en de drang om te vergelden/wraak te nemen, maar dat die grondhouding gaandeweg verandert: de woede wordt getemperd en de neiging tot agressie/geweld verdwijnt. Nussbaum spreekt dan ook van vergeving als proces (zie ook Claessen, 2017: 29-43).

\section{Voorwaardelijke vergeving}

Wanneer aan vergeving - zoals volgens Nussbaum doorgaans het geval is - voorwaarden zijn verbonden, zoals erkenning van verantwoordelijkheid, afkeuring van de misdaad, spijtbetuiging jegens het slachtoffer en de belofte en inzet tot (gedrags)verandering, spreekt Nussbaum van 'transactionele vergeving' (p. 75). Deze vorm van vergeving dient te worden onderscheiden van onvoorwaardelijke vergeving en onvoorwaardelijke liefde (p. 77). Alle drie komen in het joods-christelijke denken voor, al is met name de transactionele vergevingsvorm daarin 'gecodificeerd', aldus Nussbaum. Wat transactionele vergeving betreft, verwijst zij onder meer naar het evangelie volgens Lucas (17:3-4): 'Als je broeder zondigt, wijs hem dan terecht, en als hij zich bekeert, vergeef hem dan. Als hij zeven maal op een dag tegen je zou zondigen en zeven maal tegen je komt zeggen: "ik heb er spijt van”, dan moet je hem vergeven.' Niettemin is zij 'bovenal een constructie van de georganiseerde kerk', waarbij kan worden gedacht aan het Dies Irae, één van de gezaghebbende rituele teksten over berouw en vergeving (p. 85). Kern van de zaak: zondaars komen enkel in aanmerking voor vergeving na een proces van schuldbekentenis, berouw en boetedoening, terwijl het christendom bovendien grote nadruk legt op 'nederigheid en zelfverlaging' en 'inferioriteit en intrinsieke waardeloosheid' van de zondaar (p. 90-92). Nussbaums conclusie luidt dat vergelding en voorwaardelijke vergeving niet op gespannen voet staan met elkaar of elkaar uitsluiten, maar dat ze juist complementair zijn: 'Het vergevingsproces [is] op zich gewelddadig [...] jegens het ik van de persoon' (p. 91) en 'De boeteling wordt simpelweg getormenteerd door boetedoening', terwijl 'het slachtoffer wordt aangemoedigd om van het schouwspel van deze gang door het stof te genieten als een intrinsiek waardevol onderdeel van het vergevingsproces' (p. 92). Evenals bij vergelding in de betekenis van wraakneming is er ook bij transactionele vergeving sprake van een zekere mate van hardvochtigheid. Kortom: transactionele vergeving vormt geen geschikt alternatief voor woede, nu de twee aan woede 'inherente fouten' (i.e. de vergeldings- en de statusmisvatting) eveneens schuilgaan achter deze vorm van vergeving (p. 93).

\section{Onvoorwaardelijke vergeving}

Wat beschouwt Nussbaum dan wel als geschikte alternatieven voor woede en dientengevolge voor vergelding en transactionele vergeving? $\mathrm{Na}$ het afvallen van voorwaardelijke vergeving onderzoekt zij of onvoorwaardelijke vergeving een 
geschikt alternatief is. Onvoorwaardelijke vergeving is eveneens te vinden in het joods-christelijke denken; onder meer in Psalm 103 en met name in de evangeliën. Echter, ook onvoorwaardelijke vergeving is volgens Nussbaum 'zelden vrij van een bepaald soort vergeldingsdrang, althans aanvankelijk': binnen de context van onvoorwaardelijke vergeving wordt vergelding immers als een legitiem doel gezien, maar wordt zij genadiglijk losgelaten (p. 95). Een ander probleem is dat onvoorwaardelijke vergeving kan dienen 'als kanaal voor het verlangen naar vergelding': degene die voorwendt onvoorwaardelijk te vergeven neemt dan een moreel superieure houding aan tegenover de zondaar. Kortom: ook onvoorwaardelijke vergeving flirt in de visie van Nussbaum als het ware met de weg van de vergelding en/of met de weg van de persoonlijke status (zie par. 3). Tot slot is onvoorwaardelijke vergeving niet noodzakelijk gericht op transitie: 'Onvoorwaardelijke vergeving gaat nog over het verleden, en ze biedt ons niets concreets waarmee we voorwaarts kunnen gaan. Ze wist alleen maar iets uit, maar behelst geen constructieve toekomstgerichte houding. Ze zou vergezeld kunnen gaan van liefde en goede plannen - of niet' (p. 96). Kortom: ook onvoorwaardelijke vergeving is niet onproblematisch.

\section{Onvoorwaardelijke liefde}

Er bestaat volgens Nussbaum evenwel een versie van onvoorwaardelijke vergeving die vrijwel identiek is aan onvoorwaardelijke liefde, omdat er geen sprake is van 'een zweem van superioriteit of wraakzucht' (p. 96). Nussbaum prefereert de term onvoorwaardelijke liefde voor deze versie van onvoorwaardelijke vergeving en verwijst in dit verband onder meer naar de Bergrede, waarin te lezen valt: 'Heb je vijanden lief en bid voor wie je vervolgen' (Matteüs 5:44) en 'Heb je vijanden lief, wees goed voor wie je haten' (Lucas 6:27). Waarom onvoorwaardelijke liefde beter past dan onvoorwaardelijke vergeving? Omdat 'er geen gewag wordt gemaakt van het laten varen van voorgaande woede', omdat liefde 'een eerste reactie [is], niet een vervanging van een eerdere vergeldingsdrang' (p. 97). Ook bespreekt Nussbaum de bekende parabel van de verloren zoon (Lucas 15). Hoewel de traditionele lezing wijst in de richting van voorwaardelijke vergeving door de vader na het berouw van zijn zoon, wijst Nussbaum - in lijn met verscheidene andere auteurs (Nouwen, 2016; Claessen, 2012) - erop dat de houding van de vader wordt gekenmerkt door niets anders dan onvoorwaardelijke liefde, aangezien hij niet eerst in woede ontsteekt en hij ook geen acht slaat op het berouw van zijn zoon (p. 98-100). ${ }^{12}$ 


\section{Rationeel strafrecht: geen vergelding, wel preventie en menselijk welzijn}

Na deze beschouwingen over woede en vergeving gaat Nussbaum over tot toepassing ervan op het niveau van de persoonlijke relaties, het middendomein ${ }^{13}$ en het politieke domein uitgesplitst naar alledaagse gerechtigheid en revolutionaire gerechtigheid. ${ }^{14}$ Voor deze bijdrage is primair de alledaagse gerechtigheid in het politieke domein van belang, aangezien Nussbaum haar ideeën over woede en vergeving daarin betrekt op het thema misdaad en straf. Op basis van het voorgaande zal het geen verbazing wekken dat Nussbaum in het kader van het criminaliteitsvraagstuk niet pleit voor strategieën en reacties op misdaad die focussen op vergelding. Ze voelt zich juist sterk aangetrokken tot het non-retributivistische gedachtegoed van Socrates, Plato ${ }^{15}$ en de Stoïcijnen alsook tot dat van latere utilitaristen als Jeremy Bentham en in het bijzonder John Stuart Mill. Ook de non-retributivistische ideeën van Mahatma Gandhi, Martin Luther King jr. en Nelson Mandela betrekt ze uitvoerig in haar werk. ${ }^{16}$ Nussbaum pleit voor 'een filosofisch soort welfarisme' dat 'zonder meer deontologische elementen' bevat, getuige haar eerdere werk over politieke gerechtigheid (p. 203). ${ }^{17}$ Concreter gesteld: in het kader van het criminaliteitsvraagstuk pleit Nussbaum voor strategieën en reacties op misdaad die gericht zijn op preventie - en via die weg op de realisering van menselijk welzijn. Hoewel Nussbaum pleit voor een aanpak van

13 Het middendomein is 'de sfeer van de talrijke transacties die we hebben met mensen en sociale groepen die niet onze beste vrienden en ook niet onze politieke instituties of hun officiële vertegenwoordigers zijn' (p. 18).

14 Revolutionaire gerechtigheid betreft het ageren tegen 'groot onrecht' in een samenleving. Nussbaum gaat wat revolutionaire gerechtigheid betreft hoofdzakelijk te rade bij het gedachtegoed en handelen van Mahatma Gandhi (het Britse kolonialisme in India), Martin Luther King jr. (de segregatie tussen blank en zwart in Amerika) en Nelson Mandela (de apartheid in Zuid-Afrika).

15 Nussbaum haalt instemmend Plato aan die in diens Protagoras schrijft: 'Degene die rationeel probeert te straffen, doet dat niet met het oog op de wandaad die nu in het verleden ligt - want wat gebeurd is, is gebeurd - maar met het oog op de toekomst, opdat de overtreding niet herhaald zal worden, noch door hem noch door de anderen die zorgen dat hij gestraft wordt' (p. 200). Nussbaum had ook kunnen verwijzen naar Plato's De ideale staat waarin hij een dialoog beschrijft tussen Socrates en Polemarchos over het thema goed gedrag met de volgende conclusie: 'We stellen dus vast dat een mens zich niet goed gedraagt als het een ander ten gevolge van zijn gedrag slecht gaat, ook al is die ander een vijand. [...] Als iemand dus zegt dat goed gedrag inhoudt dat men zijn medemensen behandelt zoals men hun verschuldigd is, en als dat voor hem dan betekent dat een mens zijn vijanden slecht behoort te behandelen, dan geeft hij blijk van gebrek aan inzicht, want we constateren dat het nooit goed kan zijn iemand slecht te behandelen.'(Plato, 2005: 16-22; aangehaald in: Claessen, 2010: 134)

16 Zie hierover in het bijzonder hoofdstuk 7 uit Anger and Forgiveness over revolutionaire gerechtigheid.

17 Zie ook p. 224: 'Enkele van de vertrouwde bezwaren tegen de consequentialistische theorieën over straf (namelijk dat die harde of vernederende straffen of het straffen van onschuldigen kunnen rechtvaardigen) verdwijnen als we erop wijzen dat het soort consequentialisme dat ik verdedig de bescherming van de waardigheid en het niet-vernederen als enkele van de meest fundamentele "consequenties" inhoudt, omdat dit dingen zijn waar burgers recht op hebben op grond van gerechtigheid.' Zie voor Nussbaums eerdere werk over politieke gerechtigheid onder andere: Nussbaum, 2011 en 2013. 
misdaad met 'een instelling van woedeloosheid' (p. 207), acht ze transitiewoede wel geoorloofd (p. 209).

\section{Preventie ex ante en ex post - en genade}

Wat betreft preventie ex post pleit zij voor een preventiegericht strafrechtstelsel. Het is haar echter niet alleen te doen om preventie ex post, dat wil zeggen preventie ter voorkoming van nieuwe strafbare feiten middels straf. Eerst en vooral gaat het haar om preventie ex ante, dat wil zeggen preventie ter voorkoming van strafbare feiten middels opvoeding, onderwijs, sociale verbetering, enzovoort. Bovendien worden preventie ex post en preventie ex ante - via de Grieks-Romeinse idee van de genade ${ }^{18}$ - met elkaar in verband gebracht: indien preventie ex ante tekortschiet, komt preventie ex post in beeld, maar preventie ex post leidt idealiter tot 'hernieuwde toewijding aan het ex-anteperspectief':

'Naast de gebruikelijke aandacht voor specifieke en algemene afschrikking, en soms een inperking van de vrijheid, zal de [...] rechter zich ook afvragen hoe we in een wereld van menselijke zwakheid zo goed mogelijk met elkaar zouden kunnen samenleven. Deze aandacht neemt soms de vorm aan van specifieke genade voor een specifieke dader. Maar omdat de [...] rechter de achterliggende omstandigheden probeert te begrijpen die bij deze misdaad een rol spelen, moet hij ook een stap verder gaan en tot een algemenere afweging komen van wat er ex ante gedaan kan worden om te voorkomen dat het nog eens gebeurt' (p. 241).

Evenals onvoorwaardelijke liefde impliceert genade een woedeloze geesteshouding op grond waarvan de misdaad wordt afgekeurd, maar tegelijkertijd de dader wordt gezien als meer en beter dan zijn misdaad, de dader in staat wordt geacht in de toekomst het goede te doen en de aan de dader op te leggen straf op deze inzichten wordt afgestemd (p. 242-243).

\section{De mythe over Orestes: de transformatie naar een rationeel strafrecht}

Zowel aan het begin van haar boek als in het hoofdstuk over alledaagse gerechtigheid in het politieke domein verwijst Nussbaum naar de Griekse mythe over Orestes: Orestes die in opdracht van de god Apollo zijn vader Agamemnon wreekt door diens moordenaar Klytaimnestra (nota bene Orestes' moeder en Agamemnons echtgenote) te doden, wordt vervolgens achtervolgd door de wraakgodinnen (Furiën/Erinyen). Deze eisen zijn bloed, want bloed moet met bloed worden gewroken. Wanneer Orestes op voorspraak van Apollo zijn heil zoekt bij Pallas Athena, besluit deze godin van de wijsheid de Areopagos op te richten, een heuse 
rechtbank waarbinnen de meest wijze mannen van de stad over Orestes' zaak zullen beslissen. Wanneer bij het staken van de stemmen Pallas Athena Orestes vrijspreekt, zijn de wraakgodinnen furieus en dreigen zij de stad Athene te vervloeken. Pallas Athena weet hen evenwel middels overreding gunstig te stemmen: ze krijgen ook een plek toebedeeld in het nieuwe rechtssysteem. Echter, daarbinnen zullen zij niet optreden als Furiën/Erinyen, maar als welwillenden (Eumeniden). Dat betekent in de visie van Nussbaum dat onrecht wel serieus wordt genomen en wordt bestraft, maar dat bestraffing niet plaatsvindt vanuit 'retributivistisch [...] sentiment', maar met oog op 'afschrikking en algemeen nut' (p. 13-14). In de woorden van Nussbaum:

'De Furiën, of Erinyen, die enkel bestaan om overtreders op te sporen en hun pijn en kwaad toe te brengen, zijn ineens vriendelijk en toekomstgericht; ze zegenen het land en streven het welzijn van de bevolking na. Ze gaan ook rationeel luisteren naar de stem van de overredingskracht. Als bewakers van de wet blijven ze wetsovertredingen ontmoedigen door angst aan te jagen. Maar ze onderdrukken hun woede. Ze richten zich op het voorkómen van wandaden en niet op vergelding' (p. 198-199). ${ }^{19}$

In de mythe over Orestes gaat het om twee transformaties: 1. de overgang van privaat strafrecht naar publiek strafrecht en 2. de overgang van irrationele vergelding/wraakneming naar redelijke rechtspraak gericht op preventie c.q. 'correctie en afschrikking' (p. 200) (zie ook: Claessen, 2018). In feite pleit Nussbaum voor een rechtstelsel zoals gepresenteerd in de mythe over Orestes, omdat het daarin - in de visie van Nussbaum - gaat om een 'heilzaam toekomstgericht systeem van gerechtigheid' (p. 55).

\section{Nussbaums beoordeling van de ideeën van Duff en Braithwaite}

Extra aandacht besteedt Nussbaum aan wat ze noemt 'ingewikkeldere' en 'genuanceerdere' vormen van retributivisme (p. 215 en 222). Daartoe rekent zij onder meer het gedachtegoed van de Schotse rechtsfilosoof Antony Duff (Duff, 2001, 2011). Enerzijds onderschrijft zij Duffs idee dat strafrecht inhoudt 'ter verantwoording roepen', hetgeen een bepaalde mate van toekomst- en veranderingsgerichtheid impliceert, anderzijds wijst zij Duffs klassiek-retributivistische opvatting af dat 'de schuldige het verdient om (op de een of andere manier) te lijden, en dat het een gepast doel van het strafrecht is om hem dat lijden te laten ondergaan' (p. 220-221). Zij voegt hieraan toe:

19 Opmerkelijk is dat Nussbaum woede en vergelding wel problematiseert, maar angst en afschrikking niet. De vraag is: kan het angst aanjagen en afschrikken van (potentiële) daders in verband worden gebracht met onvoorwaardelijke liefde? Bestaat er zoiets als 'transitieangst'? Daarover zwijgt Nussbaum helaas. Zie over mijn opvatting dat liefde/compassie tot zowel een softe als een harde aanpak, inclusief afschrikking, kan leiden: Claessen, 2017: 88-89. 
"Het retributivisme dat hij voorstaat is een "confrontatie" met de overtreder. Het moet zich richten op communicatie en niet op lijden, en moet als doel hebben het toekomstige gedrag te beïnvloeden [...]. Leidt straf feitelijk tot erkenning en verandering, of vaker tot geharde overtreders? Hoe kan een systeem dat nog steeds een soort straf is er echt in slagen om een boodschap over te brengen die bij zou dragen aan positieve verandering?' (p. 221). ${ }^{20}$

Nussbaum bespreekt voorts het herstelrechtelijke gedachtegoed van de Australische criminoloog John Braithwaite (Braithwaite, 1989 en 2002), omdat ook dit aantrekkelijke kanten heeft, nu ook Braithwaites uiteindelijke doel is 'om mensen af te houden van de misdaad', en wel via confrontatie en re-integratie in het kader van herstelgericht groepsoverleg (p. 234). Om de morele boodschap over te brengen dat misdaad onaanvaardbaar is, ziet Braithwaite vooral heil in het opwekken bij de dader van schaamte (p. 235). Volgens Nussbaum is schaamte evenwel een precaire emotie, aangezien zij niet zozeer de verwerping van de misdaad inhoudt als wel 'een constant gevoel van volledig tekortschieten als persoon' (p. 239). Belangrijker, want gericht tegen herstelrecht an sich, is haar bezwaar tegen privatisering van de strafrechtspleging:

'Er is absoluut geen reden om een algehele theorie te aanvaarden dat de gemeenschap de plek is waar rechtgesproken wordt, of, zoals Braithwaite lijkt te beweren, dat de belangrijkste vertegenwoordiger van het recht altijd als eerste de gemeenschap moet zijn en pas daarna, als tweede, het rechtstelsel. Het is net als met het privatiseren van andere zaken: de overheid kan daarvoor kiezen als redelijkerwijs aangenomen kan worden dat het private systeem beter zal werken dan de gebruikelijke publieke aanpak' - quod non (p. 238).

Conclusie: ondanks positieve elementen kunnen de ideeën van Duff en Braithwaite Nussbaums toets der kritiek niet doorstaan.

20 Deze vragen kunnen evenzeer worden gesteld bij de ideeën van de Franse filosofe Simone Weil die schrijft: 'Zij die zo van het goede zijn vervreemd dat zij kwaad om zich heen willen verspreiden, kunnen niet anders meer in het goede worden geïntegreerd dan doordat zij zelf kwaad ondergaan. Hun moet zoveel kwaad worden berokkend, dat diep in henzelf de stem van de volkomen onschuld ontwaakt, die verbaasd zegt: "Waarom doet men mij kwaad?" Dit onschuldige deel van de ziel van de misdadiger moet worden gevoed en moet groeien, totdat het zelf een innerlijke rechtbank in de ziel gaat vormen, die de vroegere misdaden berecht en veroordeelt en hen vervolgens, met hulp van de genade, vergeeft. De strafvoltrekking is daarmee voleindigd; de schuldige is opnieuw opgenomen in het goede, en moet in het openbaar en plechtig in de samenleving worden gereïntegreerd. Straffen is niets anders dan dat. [...] De straf is enkel een procedé om het zuivere goede te verschaffen aan mensen die het niet verlangen; de kunst om te straffen is de kunst om bij de misdadigers het verlangen naar het zuivere goede op te wekken door middel van pijn [...]' (Weil, 1990). Weil merkt overigens zelf op dat straf is verworden tot 'lafhartige wraakneming'. 


\section{Nussbaums ideeën: een kritische toets}

De vraag is of Nussbaums ideeën zelf de toets der kritiek kunnen doorstaan. Bij de toets die ik hier zal aanleggen, zal ik mij richten op de kern van Nussbaums pleidooi, inhoudende de invoering van een strafrechtstelsel waarin woede (transitiewoede uitgezonderd) en vergelding(sdrang)/wraak(zucht) geen rol spelen en waarin exclusief wordt gefocust op preventie en menselijk welzijn. ${ }^{21}$ Laat ik vooropstellen dat ik het normatief gezien in de kern met Nussbaum eens ben: ook ik wijs vergelding in de zin van proportionele wraakneming op morele gronden af (Claessen, 2010: hoofdstuk 3). Ik doe dat op basis van de morele basisregel 'Gij zult een ander niet schaden' (tenzij ter verdediging) die deel uitmaakt van de Gulden Regel die de mens opdraagt zijn medemens te behandelen zoals hijzelf behandeld wil worden. Let wel: de Gulden Regel staat voor veel meer dan niet-schaden; in feite roept deze regel op tot een geest van onvoorwaardelijke liefde die aanzet tot actief goeddoen. Dat op de vergelding van kwaad met kwaad een moreel taboe rust, betekent echter niet dat het bestaan van woede en vergeldingsdrang/wraakzucht dient te worden ontkend. Evenmin betekent dit dat de gerechtigheid geen reactie op misdaad zou eisen. De morele eis dat op misdaad wordt gereageerd, dient echter niet te worden verward met of inhoud te worden gegeven door de menselijke neiging de onrechtpleger te laten lijden. Mijn ideaal - afgeleid uit de Gulden Regel - is vergelding van kwaad met goed, waarbij 'goed' kan worden opgevat in termen van preventie ex ante en ex post (primair middels resocialisatie en behandeling, subsidiair middels afschrikking en opsluiting) en menselijk welzijn - uit te breiden met concepten als herstel van schade en relaties en verzoening die eveneens bijdragen aan preventie en menselijk welzijn (zie over de betekenis van 'goodness' in het kader van reacties op misdaad: Claessen, 2017: 88-89).

\section{Het belang van kanalisatie en transformatie van woede}

Echter, terwijl Nussbaum pleit voor een publiek strafrecht dat exclusief focust op preventie en menselijk welzijn, ben ik van mening dat het gezien de condition humaine op dit moment onmogelijk is om voldoende democratisch draagvlak te genereren voor het implementeren van een strafrechtstelsel dat voorbijgaat aan woede en vergelding(sdrang)/wraak(zucht) - zeker nu sprake is van 'een cultuur waarin de herwaardering van emoties en daarmee de gevoeligheid voor leed gemeengoed zijn geworden' en '[h] et recht [...] niet onder deze "sensitivering" uit [lijkt] te komen' (Leest, 2002: 59; zie ook: Beunders, 2018). Zoals gezegd: woede en vergeldingsdrang/wraakzucht bestaan en dienen niet te worden ontkend of

21 Het is overigens merkwaardig dat Nussbaum haar boodschap van onvoorwaardelijke liefde en haar pleidooi voor een exclusief op preventie en menselijk welzijn gericht strafrechtstelsel nergens uitwerkt. De afwijzing van woede en vergelding(sdrang)/wraak(zucht), waaraan Nussbaum de meeste energie besteedt, lijkt haar automatisch in de richting te leiden van het rationele preventiedenken, in het kader waarvan ook afschrikking en opsluiting een rol spelen. Vanuit haar boodschap van onvoorwaardelijke liefde komen in ieder geval geen 'originele' reacties op misdaad voort - behalve wellicht wanneer ze over genade schrijft. Zie ook noot 16. 
veronachtzaamd. Waar het mijns inziens dan ook om zou moeten gaan in het strafrecht, is dat vergeldingsdrang/wraakzucht en de daarachter liggende woede worden gekanaliseerd, dat wil zeggen dat zij, wanneer zij er zijn, op beschaafde wijze worden geuit en gedemonstreerd, en dat zij worden getransformeerd, inhoudende dat de achter vergelding(sdrang)/wraak(zucht) schuilgaande destructieve woede gericht op het lijden van de onrechtpleger wordt omgebogen naar een constructieve woede gericht op een betere toekomst en het welzijn van allen, lees: transitiewoede. Kortom: het strafrecht dient een overgang mogelijk te maken en te stimuleren van 'Wat een schande! Hiervoor moet de dader lijden!' naar 'Wat een schande! Daar moet iets aan gedaan worden!'. Hoewel het officiële verhaal achter het publieke strafrecht luidt dat het strafproces en de strafoplegging negatieve emoties die door de misdaad bij het slachtoffer en de samenleving jegens de dader zijn ontstaan, op beschaafde wijze weten te kanaliseren en om te buigen, durf ik te betwisten dat dit daadwerkelijk gebeurt (zie ook: Leest, 2004). Integendeel, negatieve emoties worden in en door het publieke strafrecht vaak juist versterkt, omdat dit koude, zakelijke, gebureaucratiseerde systeem stammend uit The Age of Reason zich in feite geen raad weet met emoties (Claessen, 2017: 79).

\section{Van Furiën/Erinyen naar Eumeniden door 'emotiearbeid' en wederzijdse empathie}

De fout die Nussbaum mijns inziens maakt, is dat zij top-down pleit voor een publiek strafrecht dat niet langer gericht is op woede en vergelding(sdrang)/ wraak(zucht). Dat is veel en veel te voorbarig, daar de meeste mensen, nadat een ernstige misdaad is gepleegd, in ieder geval in eerste instantie meer op Furiën/ Erinyen dan op Eumeniden lijken. De kans dat mensen nog furieuzer worden, is groot, wanneer zij het eumenidische perspectief van de rechter of jury niet begrijpen en zij zich bovendien niet serieus genomen voelen nu het uit misdaad ontstane conflict hun door de overheid wordt ontnomen, omdat zij niet in staat worden geacht om 'redelijk' te reageren. Ik acht het daarom - in tegenstelling tot Nussbaum gezien haar reactie op Braithwaites herstelrechtelijke ideeëngoed vruchtbaarder om in en rondom het publieke strafrecht contexten te creëren waarbinnen voor het slachtoffer en de gemeenschap een transitie van Furiën/Erinyen naar Eumeniden mogelijk wordt gemaakt, een transitie die naast redelijke argumentatie ook en vooral 'emotiearbeid' en het stimuleren van wederzijdse empathie vereist (Leest, 2002: 57; Claessen, 2017: 83-84). In praktijk blijken herstelgerichte processen en praktijken een dergelijke context te vormen. Door de implementatie van dergelijke processen en praktijken vindt niet alleen een remoralisering, maar ook een minstens zo belangrijke en noodzakelijke reritualisering van de reactie op misdaad plaats: 'De herstelconferentie lijkt [...] een belangrijke moreel-emotieve functie te hebben: ze vormt een gecontroleerde ceremonie die slachtoffers de ruimte geeft expressie te geven aan hun sentimenten en erkenning te vragen. In de praktijk leidt dit vaker tot mildering van de retributieve verlangens van slachtoffers dan versterking ervan.' (Leest, 2004: 46) 


\section{Een idealistisch perspectief - zonder dwang maar met handvatten graag}

Normatief gezien is er volgens Nussbaum enkel ruimte voor reacties op misdaad voortkomend uit onvoorwaardelijke liefde. Dat laat evenwel onverlet dat onvoorwaardelijke liefde voor de meeste mensen te hoog gegrepen is. Het is opmerkelijk dat, terwijl Nussbaum stelt dat in praktijk vrijwel alle reacties op misdaad gekenmerkt worden door woede en op zijn minst omgeven zijn met een zweem van vergeldingsdrang/wraakzucht, zij tegelijkertijd exclusief pleit voor reacties op misdaad vanuit onvoorwaardelijke liefde. Enerzijds onderkent ze de condition humaine en overdrijft ze deze naar mijn mening, anderzijds kan ze vanuit normatief perspectief niet anders dan uitsluitend gedragingen uit onvoorwaardelijke liefde moreel gelegitimeerd achten. Anders dan in haar eerdere werk hangt Nussbaum in Anger and Forgiveness een wel erg idealistisch perspectief aan dat bovendien - en daar zit voor mijzelf vooral de pijn - een nogal dwingend karakter krijgt. Vervolgens reikt ze de mens nauwelijks handvatten aan om zich dit perspectief eigen te maken. De suggesties die ze doet - bijvoorbeeld 'de dingen zie[n] vanuit het gezichtspunt van anderen en begrijp[en] wat ze meemaken’ (p. 70) - komen er in de kern op neer 'dat vermijding van woede vereist dat je minder verwikkeld blijft in de narcistische "wonden” van het ego' (p. 69). Zeker waar, maar ga er maar aan staan!

\section{Handvatten vanuit de psychologie om met woede om te gaan}

Het gaat wellicht ook het werk van de hedendaagse filosoof te buiten om uiteen te zetten hoe woede het beste 'aangepakt' kan worden; dit lijkt tegenwoordig meer voer voor psychologen en therapeuten. ${ }^{22}$ Zo bespreekt de Amerikaanse psycholoog Daniel Goleman in zijn boek Destructive Emotions drie manieren om destructieve emoties, waaronder woede, aan te pakken: 1 . door er positieve emoties tegenover te plaatsen, bijvoorbeeld liefde/compassie; 2. door met behulp van meditatie 'de ultieme natuur' ervan in te zien inhoudende dat ze 'geen inherente soliditeit' hebben, lees: dat ze 'leeg' zijn en 3. door hen te transformeren door ze als katalysator te gebruiken (Goleman, 2011: 120-121). In zijn boek Emotional Intelligence beschrijft Goleman twee manieren om woede te temperen: 1 . fysiologische afkoeling en afleiding en 2. het 'aanvechten' van de gedachten die de woede teweegbrengen; in feite gaat het er hierbij om eigen oordelen kritisch te bekijken, om waar mogelijk positieve gedachten toe te voegen en om compassie te tonen (2004: 96-97). Deze tweede manier sluit aan bij de door Goleman in Destructive Emotions als eerste genoemde methode, een manier/methode die ook in het kader van herstelgerichte processen en praktijken van pas kan komen, wanneer het gaat om het ontwikkelen van wederzijdse empathie. De in Destructive Emotions als

22 Zie in dit verband: Mual, 2018, waarin de auteur expliciet onderscheid maakt tussen woede die voortkomt uit escalatie van een conflict (de secundaire emotie) en 'rage', een onderliggende emotie die ons gedrag stuurt. Muals artikel is ook interessant met betrekking tot de vraag of en, zo ja, in hoeverre mediators (in strafzaken) gebruik (mogen) maken van therapeutische en psychologische interventies. 
derde genoemde methode sluit aan bij wat Nussbaum transitiewoede noemt: woede als aanjager van positieve verandering. ${ }^{23}$

\section{Stap voor stap richting onvoorwaardelijke liefde}

Aangezien woede de destructieve emotie is 'die mensen het slechtst onder controle hebben' (Goleman, 2004: 93), beschouw ik het zelf als morele winst wanneer met behulp van 'emotiearbeid' en de ontwikkeling van wederzijdse empathie (nodig voor compassie; zie: Claessen, 2017: 88-89) in het kader van herstelgerichte processen en praktijken woede wordt getemperd en/of constructief wordt aangewend. Wanneer de dader wordt vergeven op voorwaarde dat hij een bekentenis aflegt ('de waarheid' vertelt), excuses maakt en/of de aangerichte schade (symbolisch) herstelt, is dat mijns inziens eveneens morele winst - of men dit nu als vergeving kwalificeert of niet. In tegenstelling tot Nussbaum associeer ik vergevingsprocessen in beginsel ook niet met een houding van 'nederigheid en zelfverlaging' en 'inferioriteit en intrinsieke waardeloosheid' van de dader en 'een moreel superieure houding' van het slachtoffer, laat staan dat het het slachtoffer te doen zou zijn om iets als schadenfreude. De voorbeelden die Nussbaum kiest, zijn naar mijn mening vergezocht en weinig representatief voor de vergevingsprocessen zoals die zich doorgaans tussen mensen afspelen (Claessen, 2017: 29-34; De Cock, 2014). En ook in Nussbaums stelling dat vergeving - ook onvoorwaardelijke vergeving - geen hoopvol venster op de toekomst hoeft te bieden, kan ik mij niet vinden; ik sluit me graag aan bij Desmond Tutu die zijn boek over de ZuidAfrikaanse Waarheids- en Verzoeningscommissie niet voor niets als titel gaf: No future without forgiveness (Tutu, 2000). Eveneens anders dan Nussbaum maar met de Amerikaanse spirituele leraar Ram Dass, die spreekt van vergeving als a step on a ladder that goes from dualism into non-dualism, ${ }^{24}$ ga ik uit van een continuüm, waarvan de uiteinden worden gevormd door aan de ene kant woede en vergelding in de betekenis van wraak (wortelend in de illusie van afgescheidenheid) en aan de andere kant onvoorwaardelijke vergeving en liefde (wortelend in het inzicht van verbondenheid) (Claessen, 2017: 93). Transitiewoede, herstel en voorwaarde-

Ook de Dalai Lama - met wie Goleman verscheidene malen heeft gesproken over het thema destructieve emoties - lijkt het bestaan van transitiewoede te onderkennen: 'We kunnen misschien twee typen van woede onderscheiden. Het ene type zou in een positief gevoel veranderd kunnen worden. Wanneer we bijvoorbeeld uit oprecht mededogen iemand voor een verkeerde daad proberen te behoeden maar de desbetreffende persoon luistert niet, dan hebben we geen keus om hem zijn wandaden te beletten dan een zeker gebruik van geweld. Het tantrisch boeddhisme kent meditatietechnieken die tot transformatie van de woede-energie leiden. [...] Op mededogen berustende woede kan soms haar nut hebben omdat we er extra energie door krijgen en er snel door kunnen ingrijpen' (Dalai Lama, 1995: 44-45). In de regel keurt ook de Dalai Lama woede evenwel af als zijnde 'een buitengewoon ongetemde, grove, onevenwichtige gemoedsgesteldheid' (Dalai Lama, 2002a: 132). Hij schrijft, in lijn met het stoïcisme van Seneca: 'Als krachtige tegenmaatregelen nodig zijn, neem die dan zonder dat ze gepaard gaan met woede, want woede ontkracht de effectiviteit ervan. [...] Bovendien tast woede ons beoordelingsvermogen aan en we verliezen er de gevolgen op korte en langere termijn door uit het oog. [...] In de meeste gevallen blijken onder de invloed van woede genomen beslissingen onjuist' (Dalai Lama, 2002b: 170). 
lijke vergeving liggen tussen beide polen in, als tussenstappen op weg naar het ideaal van onvoorwaardelijke vergeving en liefde (lees: non-dualisme). Evenals Nussbaum houd ik het ideaal voor realiseerbaar. Geduld en een bottom-upbenadering vanuit de mens zelf zijn hierbij evenwel van groot belang.

\section{Via voorwaarden naar onvoorwaardelijke vergeving en liefde?}

Het slot van deze bijdrage wijd ik aan het ideaal van onvoorwaardelijke vergeving in de zin van onvoorwaardelijke liefde, zoals uitgedrukt in de parabel van de verloren zoon. Volgens Nussbaum gaat het hierbij om iets wat iedere 'calculatie' en alle 'legalistische formules' te boven gaat (p. 100 en 107). Die visie treffen we ook aan bij de Franse filosoof Jacques Derrida die schrijft: 'If I grant forgiveness on condition that the other confess, that the other begin to redeem himself, to transfigure his fault, to dissociate himself from it in order to ask me forgiveness, then my forgiveness begins to let itself be contaminated by an economy, a calculation that corrupts it' (Derrida, 2001: 46). Kortom: 'volwaardige' of 'echte' vergeving ligt voorbij iedere notie van geven en nemen (do ut des oftewel quid pro quo). Het betreft een waarlijk 'ongegronde' gift. Deze visie van Derrida op vergeving moet worden geplaatst tegen de achtergrond van diens ideeën omtrent recht en rechtvaardigheid: 'Recht is niet rechtvaardigheid. Het recht is de omgeving van de berekening; en het is rechtvaardig dat er recht is, maar rechtvaardigheid is niet te berekenen, ze vereist dat men rekent met het onberekenbare' (Derrida, 2013: 63; zo ook Weil, 1990). Rechtvaardigheid is iets wat in een concrete situatie 'gebeurt' oftewel 'plaatsvindt' (of niet), zo ook onvoorwaardelijke vergeving. Ook vergeving vereist een rekenen met het onberekenbare. En toch stelt Derrida - daarmee één van de vele paradoxen van vergeving weergevend: 'If we want to embody an unconditional forgiveness [...], we have to go through conditions. We have to negotiate the unconditional and the conditional' (Derrida, 2001: 58). Zou het mogelijk zijn om een rechtstelsel te ontwerpen dat het ideaal van onvoorwaardelijke vergeving en liefde uiteindelijk een stukje dichterbij brengt, door daders en slachtoffers een pad te bieden dat langs transitiewoede, herstel en voorwaardelijke vergeving kronkelt? Braithwaite doet in dit verband een beroep op herstelrecht:

"We should not [...] "expect" forgiveness in the public sphere. Rather, forgiveness should be a light on the hill in a politics of hope. [...] Restorative justice advocacy for me is itself the path to that potential politics of hope. [...] A restorative justice that expands the sphere of forgiveness [...] in the criminal justice system [...] is therefore a light on the hill' (Braithwaite, 2016: 87-89 en 92).

Onvoorwaardelijke vergeving en liefde als uitnodigende lichten op een berg in de verte. Hoe moeilijk realiseerbaar ook, we hebben dergelijke idealen nodig om ons morele kompas op te kunnen richten. 


\section{Persoonlijke noot}

Deze zomer was ik op vakantie in Israël, een land waar de verwezenlijking van deze idealen verder weg lijkt dan waar ook, maar tevens het gebied waar deze idealen door Jezus werden verkondigd. Ik was onder de indruk van steden als Jeruzalem, Nazareth en Bethlehem, maar de meeste indruk op mij maakte de heuvel van de zaligsprekingen die uitziet over het meer van Galilea - een serene oase in een grotendeels dor landschap. 'Gelukkig zij die hongeren en dorsten naar gerechtigheid, want zij zullen verzadigd worden. Gelukkig de barmhartigen, want zij zullen barmhartigheid ondervinden. [...] Gelukkig de vredestichters, want zij zullen kinderen van God genoemd worden' (Matteüs 5:6-9). De woorden - geschreven op bordjes langs een kronkelig pad - ontroerden me en deden me denken aan het Bijbelverhaal over de overspelige vrouw, waarin het gaat om recht doen na misdaad (Johannes 8:1-11). Wanneer de schriftgeleerden Jezus vragen wat de gerechtigheid eist (de wet van Mozes schrijft bij overspel steniging voor, maar ook dat de aanklagers de eerste steen werpen), zegt Jezus tegen hen: 'Wie van u zonder zonde is, laat die de eerste steen dan werpen.' Nadat de schriftgeleerden één voor één zijn afgedropen, zegt Jezus tegen de vrouw: 'Ga heen en zondig niet meer.' De taal van de liefde zegt: 'Heb compassie met iemand die over de grens is gegaan. Je had het zelf kunnen zijn' (Ter Linden, 2018: 187). De taal van de liefde 'is de enige taal die ons openen kan. Die ons genezen kan. Die deze wereld redden kan' (Ter Linden, 2018: 194). Dat lijkt ook Nussbaum begrepen te hebben. Maar (vergeving schenkende) liefde laat zich niet dwingen. Toch is er hoop, zoals de tot inkeer gekomen misantroop Ebenezer Scrooge uit Charles Dickens' kerstvertelling ons laat zien. Het is Scrooge die - inmiddels figuurlijk wakker geworden - tegen de Geest van Toekomstige Kerstfeesten zegt: 'Het handelen van mensen voorspelt een bepaalde afloop, die het moet krijgen als ze op dezelfde manier doorgaan. [...] Maar als ze een andere weg inslaan, zal ook de afloop anders zijn' (2017: 117). Om tot inkeer te komen en om die andere weg in te slaan heeft Scrooge de hulp nodig van drie geesten, die hem niet dwingen maar hem in zijn hart weten te raken door hem simpelweg te confronteren met zijn keuzes uit het verleden en de consequenties daarvan in het heden en met zijn mogelijke keuzes in het heden en de mogelijke consequenties daarvan in de toekomst. Moge de geest van Kerstmis ook $\mathrm{u}$ inzicht en vrede brengen.

\section{Literatuur}

Beunders, H. (2018) Hoeveel recht heeft de emotie?: Over straffen in de slachtoffercultuur. Amsterdam: Amsterdam University Press.

Braithwaite, J. (1989) Crime, Shame, and Reintegration. Cambridge: Cambridge University Press.

Braithwaite, J. (2002) Restorative Justice and Responsive Regulation. New York: Oxford University Press.

Braithwaite, J. (2016) Redeeming the 'F' Word in Restorative Justice. Oxford Journal of Law and Religion, 5, 79-93. 
Breebaart, L. (2016) Nussbaum: 'Kracht zit in zelfbeheersing, niet in woede'. Trouw 17 december.

Claessen, J. (2010) Misdaad en straf. Een herbezinning op het strafrecht vanuit mystiek perspectief. Nijmegen: Wolf Legal Publishers.

Claessen, J. (2012) Over vergeving \& verzoening, ontroering en de parabel van de verloren zoon. Tijdschrift voor Herstelrecht, 3, 64-68.

Claessen, J. (2017) Forgiveness in Criminal Law through Incorporating Restorative Mediation. Oisterwijk: Wolf Legal Publishers.

Claessen, J. (2018) Wraak, herstel en verzoening aan de hand van enkele Griekse mythen: Lezing in het kader van Musica Sacra Maastricht 2018. Oisterwijk: Wolf Legal Publishers.

Dalai Lama (1995) De kracht van het mededogen: Een nieuwe kijk op het leven. Den Haag: Bzztôh.

Dalai Lama (2002a) De weg naar vrijheid. Amsterdam: Pandora.

Dalai Lama (2002b) De veranderde geest. Bespiegelingen over waarheid, liefde en geluk. Den Haag: Bzztôh.

De Cock, J. (2014) Hotel Pardon: Wereldverhalen over verzoening. Tielt: Lannoo.

Derrida, J. (2001a) On Forgiveness. In: J. Derrida, On Cosmopolitanism and Forgiveness (p. 27-60). London/New York: Routlegde.

Derrida, J. (2001b) To Forgive: The Unforgivable and the Imprescriptible. In: J.D. Caputo, M. Scanlon \& M. Dolley (eds.), Questioning God (p. 21-51). Indiana: Indiana University Press.

Derrida, J. (2013) Kracht van wet. Het 'mystieke fundament van het gezag'. Antwerpen/Apeldoorn: Garant.

De Walsche, A. (2016) Martha Nussbaum: 'Mensen moeten in hun hart beroerd worden om verder te kijken dan het eigenbelang'. MO*Magazine 19 november.

Dickens, Ch. (2017) Een kerstvertelling. Amsterdam: Rainbow.

Duff, A.R. (2001) Punishment, Communication, and Community. Oxford: Oxford University Press.

Duff, A.R. (2011) Retributivism. In: M.D. White (ed.), Retributivism: Essays on Theory and Policy (p. 3-24). Oxford: Oxford University Press.

Endo, S. (2018) Jezus: Het verhaal van een leven. Utrecht: Kok.

Frijda, N.H. (2008) De wetten der emoties. Amsterdam: Uitgever Bert Bakker.

Giesen, P. \& R. Braams (2005) Emoties tonen je afhankelijkheid. Filosofe Martha Nussbaum over de onmisbaarheid van gevoel in het openbare leven. de Volkskrant 2 april.

Goleman, D. (2004) Emotionele intelligentie: Emoties als sleutel tot succes. Amsterdam: Olympus.

Goleman, D. (2011) Destructieve emoties: Een dialoog met de Dalai Lama. Amsterdam: Olympus.

Gryson, M. \& V. de Waele (2018) Positief agressief: Hoe woede benutten?. Leuven: Lannoo.

Jacobs, F. (2008) Een filosofie van emoties en verlangens. Amsterdam: Uitgeverij Nieuwezijds.

Leest, J. (2002) Gevoelige zaken: Een zorgethisch perspectief op herstelrecht. Nemesis, 3, 53-60.

Leest, J. (2004) Van schavot tot beschaming: De rituele functie van het straf- en herstelrecht. Filosofie \& Praktijk, 5, 36-48.

Linden, C. ter (2018) Bijbelse miniaturen: Over Adam en Eva, Kaïn en Abel, Noach, Abraham, Mozes, David, het Hooglied, Jona en Jezus. Amsterdam/Antwerpen: De Arbeiderspers.

Mual, M. (2018) De therapeutische interventie: kan en mag dat?: Interventies uit emotionally focused therapy in mediation. Tijdschrift Conflicthantering, 5, 26-31. 
Nouwen, H. (2016) Eindelijk thuis: Gedachten bij Rembrandts 'De terugkeer van de verloren zoon'. Tielt: Lannoo.

Nussbaum, M.C. (2001) Upheavels of Thought: The Intelligence of Emotions. Cambridge: Cambridge University Press.

Nussbaum, M. (2004) Oplevingen van het denken: Over de menselijke emoties. Amsterdam: Ambo/Anthos.

Nussbaum, M.C. (2011) Creating Capabilities: The Human Development Approach. Harvard: Harvard University Press.

Nussbaum, M. (2012) Mogelijkheden schepen: Een nieuwe benadering van de menselijke ontwikkeling. Amsterdam: Ambo/Anthos.

Nussbaum, M.C. (2013) Political Emotions: Why Love Matters for Justice. Harvard: Harvard University Press.

Nussbaum, M. (2014) Politieke emoties: Waarom een rechtvaardige samenleving niet zonder liefde kan. Amsterdam: Ambo/Anthos.

Nussbaum, M.C. (2016a) Anger and Forgiveness: Resentment, Generosity, Justice. New York: Oxford University Press.

Nussbaum, M. (2016b) Woede en vergeving: Wrok, ruimhartigheid, gerechtigheid. Amsterdam: Ambo/Anthos.

Plato (2005) De ideale staat. Politeia. Amsterdam: Athenaeum-Polak.

Reijen, M. van (2000) Filosoferen over emoties. Baarn: Uitgeverij H. Nelissen.

Reijen, M. van (2016) Stoïcijnse levenskunst: Evenveel geluk als wijsheid. Leusden: ISVW.

Scarre, G. (2004) After Evil: Responding to Wrongdoing. Hants/Burlington: Ashgate.

Tongeren, P. van (2013) Vergelding en verzoening versus wraak en vergeving. In: J. Ouwerkerk, Th. de Wit, J. Claessen, P. Jacobs \& S. Meijer (red.), Hoe te reageren op misdaad?: Op zoek naar de hedendaagse betekenis van preventie, vergelding en herstel (p. 81-87). Den Haag: Sdu Uitgevers.

Tutu, D. (2000) No Future Without Forgiveness. London: Transworld Publishers.

Tutu, D. \& M. Tutu (2014) The Book of Forgiving: The Fourfold Path for Healing Ourselves and Our World. London: William Collins.

Weil, S. (1990) De geschonden ziel. Over de menselijke waardigheid. Baarn: Ten Have.

Wit, M. (2004) Met woorden heb je nog geen vrijheid, Groene Amsterdammer 10 januari. 